\begin{tabular}{|c|c|}
\hline DE GRUYTER & ECONOMIC THEMES (2016) 54(1): 155-176 \\
\hline
\end{tabular}

\title{
EXTERNAL SEGMENT REPORTING IN THE REPUBLIC OF SERBIA
}

\author{
Vladimir Obradović \\ University of Kragujevac, Faculty of Economics, Serbia \\ \vobradovic@kg.ac.rs \\ Nemanja Karapavlović \\ University of Kragujevac, Faculty of Economics, Serbia \\ $\bowtie$ nkarapavlovic@kg.ac.rs
}

UDC

$657.14 / .17$

(047.32)

(497.11)

Original

scientific

paper

Received:

26.06.2015

Accepted:

23.03.2016

\begin{abstract}
The purpose of the research in this paper is to examine the regulation and practices of external segment reporting in the Republic of Serbia. The importance of research stems from a great potential usefulness of segment information for investors and creditors. The analysis of regulation suggests that the Republic of Serbia has highquality and internationally recognized basis of external segment reporting - IFRS 8. However, there is a room for improvement of IFRS 8. The analysis of practices, conducted on a sample of 500 companies, shows that companies in the Republic of Serbia, in general, do not attach great importance to the disclosure of segment information in financial statements. The practices are quite miscellaneous, which is a consequence of the flexibility of IFRS 8, but also an incomplete compliance with IFRS 8. By applying statistical techniques we have examined whether the practices of external segment reporting are related to characteristics of companies, which makes the originality of the paper. We have found that financial institutions disclose more extensive quantitative segment information in relation to other companies in the Republic of Serbia, and that companies with higher assets disclose more extensive segment information. The research indicates that there is a significant room for improving the practices of external segment reporting in the Republic of Serbia. The research results may be useful for regulators of financial reporting and preparers and auditors of financial statements.
\end{abstract}

Key words: financial reporting, segment reporting, disclosure, IFRS 8, operating segment

JEL classification: M40, M49, F30 


\section{Introduction}

Companies disclose a lot of information of different character in their general purpose financial statements. Disclosed information is mainly focused on the company as a whole. However, information relating to individual parts of the company is also often disclosed. Such information is referred to as segment information.

The importance of segment information has increased during the last decades, under the influence of the process of diversification and internationalization (globalization) of the operations of many companies. The fact that information about the financial position, performance and cash flows of a company as a whole is no longer sufficient for investors and creditors, as key (primary) users of general purpose financial statements, forced setters of financial reporting regulation (standards) to respond adequately. For this reason, today, in many countries, publication of segment information is based on appropriate officially established guidelines, i.e., standards. Under the influence of a general tendency to establish unified financial reporting practices, there is a tendency to unify the practices of segment reporting on the global basis.

Hereinafter, the attention shall be firstly paid to the causality and essence of external segment reporting. Then, the current regulation of the external segment reporting in the Republic of Serbia shall be discussed. Thereafter, the practices of external segment reporting of companies in the Republic of Serbia shall be analyzed, on the basis of financial statements for the year of 2013.

\section{The Essence and Causality of External Segment Reporting}

According to the definition of the Organisation for Economic Co-operation and Development (OECD), a segment represents distinguishable component of a diversified entity, engaged in activities which are more closely related to each other than to the activities of the rest of the entity (Haller, 2003, p. 444). A segment is a part of a company that can be specifically identified on the basis on products or services it provides, or geographic markets it serves (Wild, 2005, p. G-1). It has assets and liabilities that are separable from assets and liabilities of other parts (segments) of the company, and that generates profit or loss that is separable from the profit or loss of the rest of the company.

Starting from the essence of segments, segment reporting can be defined as the process of identifying components, i.e., segments of a company, and generating and reporting information on each of the identified components, i.e., segments (Roberts, 2010, p. 455). This process may have a dual purpose: informing internal users (managers) or informing external users (investors and creditors, primarily). Therefore, two types of segment reporting could be discussed: (a) internal segment reporting, i.e., reporting on different parts 
(components) of a company to management structures, and (b) external segment reporting, i.e., reporting on different parts of a company to external users. The subject of this paper is external segment reporting, which is performed through regular financial statements intended for a wide range of external users general purpose financial statements.

The need to report segment information in general purpose financial statements is caused by (a) diversification and (b) geographic dispersion of business activities in many companies. Namely, many companies produce and sell different kinds of products, provide different types of services or operate in many locations (continents, countries, or regions within a country). As a result, there are significant variations in profitability, level of risk exposure and growth opportunities within the same company (Radebaugh, 1997, p. 19.3), which further leads to the need for segmentation, i.e., decomposing the company for financial reporting purposes, and, then, disclosing relevant information about each identified component (part or segment).

Due to variations in profitability, level of risk exposure and growth opportunities within the same company, information about the company as a whole, although necessary, is not sufficient. In order to improve the informational usefulness of financial statements and, therefore, to provide a better basis for economic decision-making, it is useful to complete information about the company as a whole with information about its segments.

Segment information has potentially great importance for investors and creditors. Investors are primarily interested in the amount and time schedule of future returns of a company, as well as the risk of realization of returns, which influence their own cash flows. Investors invest their capital in a company as a whole, therefore, performance and prospects of the entirety are of primary importance to them. With respect to this, one might think that segment information is of low significance to them, i.e., that they would show little interest in such information. However, in order to gain a complete picture of performance and prospects of a complex (diversified and/or geographically widespread) company, investors should take into account performance and prospects of its parts, i.e., segments (Roberts, 2010, p. 458). Therefore, investors need segment information to be able to make reasonable investment decisions (Belkaoui, 1994, p. 241).

Segment information should enable investors to perceive and assess the socalled management risk, which, together with the risk arising from operating in certain industries and geographical areas, makes a very important component of the overall risk which investors are exposed to (Ijiri, 1995, p. 62). Due to the separation of the functions of ownership of a company and managing its operations, the so-called agency costs occur. They consist of (a) the costs of control as the costs that investors, i.e., owners bear to measure and observe the 
behaviour of managers, or to implement appropriate remuneration policy for managers, (b) the costs borne by managers to provide guarantees that they will not take actions that could harm owners' interests, or that they will indemnify in the case they cause the damage, and (c) the so-called "residual loss", which appears due to the fact that actions undertaken by managers differ from the actions that would be taken if owners themselves managed the company (Radebaugh, 1987, pp. 39-40). Agency costs lower the price of shares, i.e., increase the costs of capital for a company. In this context, segment information is of great importance, because it enables owners to have a deeper insight into the past management decisions and the effects of those decisions, thereby reducing the information asymmetry, i.e., differences in the levels of awareness of the company's operations, and increasing the trust between owners and managers. The aforementioned tendencies, ultimately, lead to lowering the costs of capital. If an obligation is imposed on managers to include segment information in regular financial statements, they would have no possibility to conceal the failures of some segments with good results of other segments. Managers also become exposed to stronger pressure to allocate resources to the most profitable segments, or to quickly improve the performance of those segments that are insufficiently profitable (PricewaterhouseCoopers, 2002, p. 16).

Unlike investors, creditors are primarily interested in a company's ability to meet its current and future liabilities, either through timely payment of the principal and interest, or, in the worst case, through distribution of liquidation or bankruptcy estate. In this context, creditors are interested in the estimation of future profits and cash flows of a company, whose tendencies affect the company's ability to meet its obligations on time. Creditors need information about segments of a complex company to assess its future profits and cash flows as realistically as possible.

The potential importance of segment information is best illustrated in the viewpoint of the American Association for Investment Management and Research, the forerunner of the present Chartered Financial Analysts Institute (CFA Institute). Namely, in its document from 1993, the aforementioned institution denotes segment information as necessary, vital, essential, fundamental and irreplaceable information, which is a part of the investment analysis process. As further stated in the same document: "without disaggregation, there is no sensible way to predict the overall amounts, timing or risks of an enterprise's future cash flows"(Pacter, 1993, p. 95).

The availability of adequate information about segments increases the efficiency of capital markets. Each segment information makes a company more transparent and helps the prices of securities it issues to reflect more realistically its business activities (Radebaugh, 1987, p. 57). In other words, segment information is a means for providing accurate information signals about a company's value (Swaminathan, 1991, p. 23). The better capital market 
participants (investors and creditors) understand business activities of a company, the more accurately will they estimate its value. Summing up the results of previous empirical surveys, Pacter (1993, pp. 136-137) states that segment information do have an impact on the price of securities that a company issues. Aware of this, some companies begun to voluntarily disclose information about segments, even before the official requirements establishing.

The essence of the process of making decisions about investing and landing lie in the effort to strike a balance between expected return rate and expected risk. The higher the estimated risk of certain investment or lending alternative is, the higher the rate of return required by an investor or creditor will be. Taking this into account, segment information should enable an investor or a creditor assessing more realistically: (a) the amounts and timing of future earnings and cash flows of a company, and (b) the risks of their occurrence.

The foregoing considerations point out to the key objectives of external segment reporting. According to the currently prevailing view, by providing information about various types of products that a company produces and sells or services it provides, as well as about different geographic areas, i.e., economic environments it operates in, external segment reporting should help users of financial statements to: (a) better understand past performances of the company, (b) better assess prospects for future cash flows of the company, and (c) make better informed judgments about the company as a whole (Financial Accounting Standards Board, 1997, p. 5).

\section{Professional Regulation on External Segment Reporting in the Republic of Serbia}

Since the Republic of Serbia is one of the many countries that have adopted the International Financial Reporting Standards (IFRS), the basis for external segment reporting in the Republic of Serbia is IFRS 8, entitled "Operating Segments". This standard was published in November 2006 by the International Accounting Standards Board (IASB), and it is a successor of the International Accounting Standard 14, entitled "Segment Reporting", which was published in August 1997 by the International Accounting standards Committee (IASC), the predecessor of the IASB.

IFRS 8 was, in fact, created in the United States, where it was published in June 1997 as the Statement of Financial Accounting Standards (SFAS) No. 131, entitled "Disclosures about Segments of an Enterprise and Related Information", by the Financial Accounting Standards Board (FASB). In the process of convergence of IFRS and the U.S. Generally Accepted Accounting Principles (GAAP) SFAS 131 became a part of IFRS after minor changes, replacing IAS 14, which it significantly differs from. The fact that the U.S. 
standard was accepted as a global solution by being embedded in IFRS is not surprising if we know that the U.S.A. is considered as "a pioneer in the area of segment reporting" (Radebaugh \& Gray, 1997, p. 90).

The fundamental principle of IFRS 8 is that an entity (company, enterprise) discloses segment information to enable users of its financial statements to evaluate the nature and financial effects of the business activities which it engages in and economic environments which it operates in. Defining the scope of IFRS 8, the IASB notes that this standard is intended for entities whose equity or debt instruments are traded in a public market (such as stock exchange) or are in the process of preparation for entering a public market. For the rest, i.e., unlisted, entities that follow IFRS, the application of IFRS 8 is not required, but is permitted. This means that unlisted entities may voluntarily disclose information about segments, and if they decide to do so, they need to comply with IFRS 8.

The approach to identify segments of an entity for the purposes of external reporting contained in IFRS 8 is known in the literature as the management approach, because it is based on the way management organizes segments within an entity for the purposes of making business decisions and performance evaluation. In other words, IFRS 8 prohibits the choice of segmentation dimensions to be made in advance, i.e., irrespective of the internal structure. The answer to the question what is the right basis for segmentation will be given solely by observing the internal structure of an entity.

The management approach is based on the assumption that, since created to facilitate decision-making by management, internal segmentation will also be useful for decision-making by external users. Understanding the internal organizational structure is important for external users, because it indicates the risks and opportunities that management considers to be important and allows evaluation and analyzing of the organization, structure and strategic orientation of management (Haller, 2003, p. 453). In other words, the above approach gives external users the possibility to see a company through "the eyes of management". Therefore, they can realistically anticipate the management actions that may significantly affect the future cash flows (Financial Accounting Standards Board, 1997, p. 23).

Following the example of the U.S. FASB, the IASB uses the term "operating segment" to denote each individual component of an entity: (a) that engages in business activities from which it may earn revenues and incur expenses (including revenues and expenses relating to transactions with other components of the same entity), (b) whose operating results are reviewed by the entity's individual or body with a crucial role in making operating decisions for the purpose of resource allocation and performance assessing, and (c) for which discrete financial information is available (IFRS 8, paragraph 5). 
The above definition clearly indicates that not every component of an entity is an operating segment. In order to become an operating segment, a component of an entity must have the characteristics of a profit or an investment centre. A profit centre is logical and functionally completed organizational unit within which managers, in accordance with the assigned authority, make decisions and have responsibilities for costs, revenues and profit. Managers of investment centres, in addition to the responsibility for profit (income), are also responsible for purchase and use of assets, i.e., for deciding on the level and type of investment (Malinić, 1999, pp. 52-75). Centres of expenses and centres of revenues are not considered operating segments, because they do not have concurrent responsibility for expenses and revenues, so they cannot be controlled on the basis of results. For example, an entity's corporate headquarter and research and development department, which do not generate revenues or generate revenues that are only incidental in comparison to the activities of the entity as a whole, are not operating segments. On the other hand, an operating segment can be a component of an entity that currently does not generate revenues, but will start to generate revenues (for example, the newly established organizational unit), as well as a vertically integrated component, i.e., component that mainly or exclusively sells its products or provides services to other operating segments of the same entity.

By accepting the internal structure of an entity as a basis for external segment reporting, the IASB implicitly accepted the presumption that management is trying to reflect an entity's risk and returns profile through internal segmentation (Haller, 2003, p. 453). Internal structure, i.e., the system of accountability and authority of managers, and internal reporting are usually based on products or geographical areas, but can also be based on their combination, or on some third criteria (types of customers, sales channels, legal entities, managerial expertise, character of the regulatory environment, etc.).

The first step in identification of operating segments is identification of an executive director or a group of executive directors for operating decisions with responsibility for allocating resources to segments and assessing the performances of segments. After that, it is necessary to identify operating segments that are subjects of consideration by executive directors for operating decisions. Usually they can be perceived on the basis of the organizational structure of an entity, which means that consideration of hierarchical organizational chart should be an orientation in identifying operating segments (Albrecht \& Chipalkatti, 1998). An operating segment usually has its own manager, whereas the same manager can be in charge of two or more segments. An executive director for operating decisions may also be the manager of one or more operating segments.

IFRS 8 requires segmentation of an entity for the purposes of external reporting to be one-dimensional, which means that only one set of operating 
segments should be selected. However, in some entities, executive directors simultaneously consider two or more sets of segment information for operating decisions. In such cases, in order to identify segments for external reporting purposes, additional criteria should be taken into consideration, such as the system of managers' accountability, the nature of segments' activities, and the information that is reported to the board of directors.

The explained way of identifying operating segments differs significantly from the requirements of IAS 14. IAS 14 required a two-dimensional segmentation of entities on the basis of (a) products or services and (b) geographical areas, wherein segments were referred to as "business" and "geographical". IAS 14 also required that segments were identified on the basis of internal reporting and control systems, but only if internal structure was based on production or geographical basis. If that condition was not met, the segments reported internally were not suitable for external reporting, and it was necessary to make appropriate corrections in order to create business and geographical segments.

According to IFRS 8, after identification of operating segments on the basis of internal reporting system, it is necessary to examine whether each of them meets the requirements for external reporting, i.e., whether it possesses the characteristics that are necessary for gaining the status of reportable segment or not. In other words, the segments identified on the basis of the internal reporting system (operating segments) are the only candidates for segments which will be reported externally. The process of transformation of operating segments into reportable segments consists of three phases.

The first phase is optional and it involves examining the possibility to combine operating segments. Namely, IFRS 8 allows, but does not require, two or more substantially similar operating segments to be combined to obtain a single reportable segment. Operating segments are considered to be substantially similar if they have similar economic characteristics (which, for example, may be reflected in similar average long-term performance), and if they have similarities in terms of: nature of products and services, the nature of production process, types of customers, the method of product distribution or service provision, and nature of regulatory environment. For example, if an entity has 20 stores, it is desirable to combine them into one reporting segment (Đukić, 2002, p. 22).

In the second phase, the authors examined (tested) whether operating segments, or segments formed by combining them, are significant enough for external reporting. For that purpose, the $10 \%$ threshold is applied. Namely, IFRS 8 requires: (1) total revenues of a segment (consisting of revenues from sales to external customers and revenues from sales to other segments) to be at least $10 \%$ of the total revenues of all segments; or (2) a segment's profit or loss, 
in absolute terms, to be at least $10 \%$ of (a) the total profit of the segments that reported profit, or (b) the total loss of the segments that reported loss, depending on which of the two amounts is absolutely higher; or (3) a segment's assets to be at least $10 \%$ of the total assets of all segments. However, segments that do not meet any of the above conditions can be announced reportable segments, if management believes that information about them may be relevant for financial statement users. This means that the threshold of $10 \%$ is not an absolute measure of segment materiality, and that quantitative assessment of materiality must be supplemented by qualitative analysis, because some factors that cannot be quantitatively expressed can make a segment significant.

In the third phase, the authors examined whether the sum of revenues from sales to external customers of previously identified reportable segments is at least $75 \%$ of revenues of the entity as a whole. If this condition is not met, additional reportable segments should be identified, even if they do not meet the criteria of materiality. This process, which, in fact, corrects the threshold of $10 \%$, is based on the view that segment information is more useful if it includes a significant part of business activities of an entity as a whole (Hoyle et al., 2004, 376).

In addition to the previously explained criteria for selection of reportable segments, IFRS 8 also contains a recommendation (i.e., nonbinding standpoint) about the total number of reportable segments. Namely, when the number of reportable segments exceeds ten, it should be considered whether a practical limit, beyond which segment information is too detailed, has been reached. This recommendation is based on an effort to increase the clarity of segment information which is presented to external users.

The information about operating segments that did not become reportable segments is presented under the "all other segments" item. The components that make up the mentioned item are not economically similar, but are brought together due to the fact that they are not significant enough for external reporting.

On the basis of fundamental segment reporting principle, IFRS 8 specifies segment information to be disclosed, classifying them into: (1) general information, (2) information on segments' profit or loss, assets and liabilities, and the basis for their generation and (3) the reconciliations of segment information with information about the entity as a whole.

General information includes: (a) information about the basis for identifying and combining operating segments, and (b) the types of products and services that each reportable segment derives its revenues from.

IFRS 8 provides that an entity should disclose, for each segment, the amount of profit or loss, but does not provide a definition of segment profit or loss, in terms of components (revenues and expenses) that determine profit or 
loss. The internal method of segment profit or loss calculation, established in order to satisfy the information needs of executive directors also applies for external reporting. In contrast to the disclosure of profit or loss, disclosures of segment assets and liabilities are of a conditional character. An entity should disclose the amounts of assets and liabilities of each segment only if the mentioned information is used by executive directors. The contents of segment assets and liabilities, in terms of components constituting them, should correspond to what is communicated to executive directors. If executive directors consider several measures of profit or loss, assets and liabilities, the measures that are the closest to measurement system used, on the level of the entity as a whole, should be chosen for external reporting.

The following segment information also has conditional character: (a) external revenues (revenues from transactions with parties outside the entity), (b) intersegment (internal) revenues (revenues from transactions with other segments of the same entity), (c) interest revenue, (d) interest expense, (e) annual depreciation of tangible non-current assets and amortization of intangible assets, (f) material income and expense items, (g) the interest in the profit or loss of associates and joint ventures accounted for by the equity method, (h) income tax expense or revenue, (i) material non-cash items other than depreciation and amortization, $(j)$ the amount of investment in associates and joint ventures accounted for by the equity method, and (k) capital expenditures, i.e., additional investments in non-current assets. The specified information has a conditional character because it is disclosed only (1) if it is included in the calculation of segment profit or loss (a-i items) or assets ( $\mathrm{j}-\mathrm{k}$ items), or (2) if it is otherwise regularly communicated to executive directors regardless of whether it is included in the calculation of profit or loss, or assets. The amounts of mentioned items considered by executive directors are authoritative for external reporting, but the clarification regarding the methods used to measure them should be provided. An entity may (but need not) explain the allocation of costs incurred at the level of entity, assets that are jointly used by segments and mutual liabilities of segments, to individual segments. An entity shall disclose the basis for the calculation of transactions between reportable segments (e.g. market price, cost or the price between cost and market price), the nature of changes in the way of measuring in comparison with the previous period, as well as the nature and effects of any asymmetric allocation (e.g. allocation of depreciation to segments without allocation of assets that are subject to depreciation, or vice versa). IFRS 8 provides the possibility to offset interest revenue and interest expense of a segment, but only if interest revenue is a majority of segment revenue, and executive directors rely on net interest when assessing segment performance.

Finally, an entity should disclose the reconciliations of (a) the total revenue of all reportable segments to the entity's revenues, (b) the overall profit or loss 
of all reportable segments to the entity's profit or loss, (c) the total assets of all reportable segments to the entity's assets (if segment assets are disclosed), (d) the total liabilities of reportable segments to the entity's liabilities (if segment liabilities are disclosed), and (e) other significant items of reportable segments to corresponding items of the entity. Because of the mentioned reconciliations, financial statement users are able to have a clear insight into the relationships between the information on reportable segments and the information relating to the entity as a whole (Haller, 2003, p. 460). Disclosure of reconciliation positions is a reflection of the process which is essentially the opposite of segmentation - the process of consolidation of segment information.

The costs of segment reporting on the basis of IFRS 8 are relatively low, because the segment information is already generated for management purposes. The additional advantage of the management approach is best reflected in the view of Solomons from 1968, who states that, if internally generated statements, i.e., reports of management accounting, "are the best that management can produce to guide their own decisions, then there is an initial presumption that the same statements, or less detailed versions of them, are likely best to serve the investor in making his investment and dis-investment decisions" (Radebaugh \& Gray, 1997, p. 310).

However, the management approach has disadvantages, and the most important one is the broad area for variations of segment reporting practices. Firstly, IFRS 8 allows the use of different bases for segmentation. Companies operating in the same industries and geographical locations may have a completely different scheme of internal reporting because they have adopted different organizational approaches (Herrmann \& Thomas, 1997, p. 41), so that their segment information would be incomparable. Secondly, the volume of disclosed information can vary significantly between entities, and may be in the range from the absence of any segment information (because the entity is not segmented for the purpose of internal reporting) to disclosure of very detailed segment information. Thirdly, different entities can measure the same positions (segment profit or loss, assets and liabilities) differently, which also may significantly jeopardize the comparability of segment information. One study reveals that the U.S. companies apply the standard slightly different from IFRS 8 report different measures of profit or loss, wherein the most common measures are: (a) operating profit or loss ( $41 \%$ of companies), (b) earnings before interest and taxes (24\% of companies), (c) earnings before taxes (11\% of companies), and (d) earnings before interest, taxes, depreciation and amortization $(9 \%$ of companies) (International Accounting Standards Board, 2005, p. 11).

Due to the fact that majority of segment information that IFRS 8 specifies has a conditional (non-binding) character, disclosed information on reportable segments, in some cases, might not be sufficient for users. For this reason, IFRS 8 specifies additional information that an entity should disclose if this 
information is not a part of segment disclosures. The additional information is independent of the segmentation carried out, and consists of: (1) revenues from transactions with external customers, for each product or service or a group of similar products or services, (2) revenues from transactions with external customers and non-current assets other than financial investments, for the entity's country of domicile, abroad in general and material foreign countries, and (3) revenues from transactions with major external customers or groups of customers under mutual control. An entity has a possibility to omit the information of the first and second category if this information is not available and costs of generating them are too high.

The provisions of IFRS 8 raise a number of challenges to external auditors. Auditors must well understand the operations of a company and the way it is run, and perceive whether it is segmented at all in order to form an opinion on segment information disclosed. Auditors should strive to observe a company through the eyes of management, which means that they must access the highest management levels (Deppe \& Omer, 2000, p. 53). Overview of the organizational structure and minutes of meetings of board of directors can help auditors to assess whether the segmentation presented in external statements is faithful (Albrecht \& Chipalkatti, 1998).

\section{The External Segment Reporting Practices of Companies in the Republic of Serbia}

Analysis of the external segment reporting practices of companies in the Republic of Serbia is based on the review of the notes to financial statements for 2013, which are available on the website of the Business Registers Agency of the Republic of Serbia. The analysis is conducted on a sample of 500 companies. The sample structure from the aspect of the legal form is shown in Table 1.

Table 1. Sample Structure from the Aspect of the Legal Form

\begin{tabular}{||l|c|c||}
\hline \multicolumn{1}{|c|}{ Legal form } & $\begin{array}{c}\text { Number } \\
\text { of entities }\end{array}$ & $\begin{array}{c}\text { Share } \\
\text { in the sample }\end{array}$ \\
\hline Stock company & 203 & $40.6 \%$ \\
\hline Limited liability company & 216 & $43.2 \%$ \\
\hline Public utility company & 76 & $15.2 \%$ \\
\hline Branch of a foreign legal entity & 1 & $0.2 \%$ \\
\hline Social enterprise & 2 & $0.4 \%$ \\
\hline Cooperative & 2 & $0.4 \%$ \\
\hline Total & 500 & $100.0 \%$ \\
\hline
\end{tabular}


Segment information is identified in the notes to financial statements of 33 companies in the sample, i.e., $6.6 \%$ of the analyzed companies, which can be considered as a relatively modest share. The lack of segment information in the notes to financial statements of even $93.4 \%$ of the analyzed companies can be explained by the fact that, for many of them (those that are not listed on a public capital market) disclosure of segment information is only an option, but not an obligation. However, many of the companies that are listed on the public capital market (Belgrade Stock Exchange) have not also disclosed segment information, which can be explained by the fact that these companies are not segmented for the purpose of internal reporting. In addition, the assumption that some preparers of financial statements are not sufficiently motivated to disclose segment information due to the lack of incentives from the environment, and in particular by auditors, should not be ruled out. The structure of sample companies that disclose segment information from the aspect of legal form, which is shown in Table 2, indicates that, nevertheless, some companies voluntarily disclose segment information.

Table 2. The Structure of Companies that Disclose Segment Information from the Aspect of Legal Form

\begin{tabular}{|l|c|c|}
\hline \multicolumn{1}{|c|}{ Legal form } & $\begin{array}{c}\text { Number } \\
\text { of entities }\end{array}$ & $\begin{array}{c}\text { Share } \\
\text { in the sample }\end{array}$ \\
\hline Stock company & 26 & $78.8 \%$ \\
\hline Limited liability company & 6 & $18.2 \%$ \\
\hline Public utility company & 1 & $3.0 \%$ \\
\hline Total & 33 & $100.0 \%$ \\
\hline
\end{tabular}

Financial institutions (banks and insurance companies) have a significant share in the total number of companies that disclose segment information. Out of the 33 companies, whose notes to the financial statements contain segment information, $14(42 \%)$ have the character of financial institution. If we bear in mind that 54 financial institutions are included in the sample, we can conclude that $26 \%$ of financial institutions disclose segment information. Only $4 \%$ of the other (i.e., non-financial) companies surveyed (19 out of 446) report segment information.

Many reporting entities in the sample (40\%) have not explicitly reported the basis for identification of operating segments, despite the requirement of IFRS 8. However, the names of segments or descriptions of segment activities mainly allow to unambiguously perceive the basis for segmentation. Operating segments are identified on the basis of products or services in 31 entities. One entity provides information on production and geographical segments in parallel, which is in the spirit of the previous IAS 14 that actually requested a two-dimensional segmentation, but not in the spirit of the current IFRS 8, which 
promotes one-dimensional segmentation. It is interesting to mention that this entity identifies only one production segment corresponding to the entity as a whole, which, in effect, means that product segmentation has not been done. Therefore, it can be considered that this entity identifies segments only on a geographical basis. In one case, segmentation is performed on the basis of legal entities that constitute the consolidated entity. Less than a half of the analyzed entities have disclosed the main types of products and services of each segment, which, again, shows the lack of respect of the provisions of IFRS 8.

The empirical research conducted by the famous global accounting firm PricewaterhouseCoopers (2005) on a sample of 65 companies worldwide that use IFRS shows that the majority of companies (85\%) identifies segments on the production basis. With respect to this, the dominance of the production basis for segmentation of companies in the Republic of Serbia is something that could have been expected.

The number of reportable segments of the analyzed entities, without segments that are marked as "other", ranges from 1 to 9 . One of the observed entities identifies only one reporting segment, noting that other activities are relatively insignificant due to the very small share in the total revenues. On the other hand, one entity discloses information on even 9 segments, which is close to the recommended upper limit. Another entity specifies and describes three reportable segments, but the data presented shows that one of the segments has no assets or liabilities and that it does not generate revenues or expenses; therefore this entity can, practically, be regarded as a two-segmented. The average number of reportable segments of the surveyed entities is 3.48. The absolute and relative frequencies of the number of reportable segments are shown in Table 3.

Table 3. The Frequencies of the Number of Reportable Segments

\begin{tabular}{|c|c|c|}
\hline Number of segments & Number of entities & Share \\
\hline 1 & 1 & $3.0 \%$ \\
\hline 2 & 10 & $30.3 \%$ \\
\hline 3 & 8 & $24.2 \%$ \\
\hline 4 & 8 & $24.2 \%$ \\
\hline 5 & 2 & $6.1 \%$ \\
\hline 6 & 2 & $6.1 \%$ \\
\hline 7 & 1 & $3.0 \%$ \\
\hline 8 & 0 & $0.0 \%$ \\
\hline 9 & 1 & $3.0 \%$ \\
\hline Total & 33 & $100.0 \%$ \\
\hline
\end{tabular}


The volume of the disclosed segment information varies considerably between the entities. While three of the observed entities disclose only one piece of quantitative segment information, one entity reports even 67 different pieces of quantitative information including cumulative items. The average number of the pieces of disclosed quantitative segment information, including summary items, is 16 . Table 4 shows the frequencies of the key quantitative segment information disclosure.

Table 4. The Frequencies of Segment Information Disclosure

\begin{tabular}{|l|c|c|}
\hline \multicolumn{1}{|c|}{ The character of segment information } & $\begin{array}{c}\text { Number of } \\
\text { entities disclosing } \\
\text { the information }\end{array}$ & $\begin{array}{c}\text { Share of entities } \\
\text { disclosing the } \\
\text { information }\end{array}$ \\
\hline Profit or loss & 29 & $87.9 \%$ \\
\hline Assets & 21 & $63.6 \%$ \\
\hline Liabilities & 16 & $48.5 \%$ \\
\hline Revenue & 33 & $100.0 \%$ \\
\hline Interest revenue and expense or net interest & 9 & $27.3 \%$ \\
\hline Depreciation and/or amortization expense & 14 & $42.4 \%$ \\
\hline Material items of revenues and expenses & 15 & $45.5 \%$ \\
\hline $\begin{array}{l}\text { Interest in the profit or loss of associates and } \\
\text { joint ventures }\end{array}$ & 0 & $0.0 \%$ \\
\hline Tax expense or revenue & 9 & $27.3 \%$ \\
\hline $\begin{array}{l}\text { Material non-cash items other than } \\
\text { depreciation and amortization }\end{array}$ & 11 & $33.3 \%$ \\
\hline Investment in associates and joint ventures & 3 & $3.0 \%$ \\
\hline Capital expenditures & & $9.1 \%$ \\
\hline
\end{tabular}

Four entities have not disclosed segment profits or losses, which is not in accordance with IFRS 8. If executive directors consider segment profits or losses, then those profits or losses should be communicated to external users through general purpose financial statements. If executive directors do not consider segment profits or losses, according to IFRS 8, the segments cannot even be declared operational, which means that they cannot become reporting segments.

On the other hand, some of the entities in the sample ( 9 in total) present two or three measures (levels) of segment profit or loss. If we start from the last (final) disclosed measure of profit or loss (which in 20 cases is also the only one), the most common measure of segment performance is earnings before taxes, then, taking into account frequency of use, earnings after taxes as well as operating income, as shown in Table 5. 
Table 5. Segment Performance Measures

\begin{tabular}{||l|c|c|}
\hline \multicolumn{1}{|c|}{ Measure of performance } & Number of entities & Share \\
\hline Operating income & 7 & $21.2 \%$ \\
\hline Earnings before taxes & 13 & $39.4 \%$ \\
\hline Earnings after taxes & 9 & $27.3 \%$ \\
\hline Not disclosed & 4 & $12.1 \%$ \\
\hline Total & 33 & $100.0 \%$ \\
\hline
\end{tabular}

Although all the entities present segment revenues, even 20 entities do not clearly separate revenues to internal and external components. One entity presents total of segment capital and liabilities, but does not specify the amount of liabilities. Six entities present interest revenue and expense, while three entities present net interest as the difference between interest revenue and interest expense, as allowed by IFRS 8. In some cases, the reconciliation of segment information (profit or loss, revenues, assets and liabilities) to the corresponding information about the entity as a whole is presented, but in some cases it is not. Finally, it should be noted that entities generally do not disclose the basis for calculation of internal transactions (transactions between segments), although IFRS 8 requires entities to do so.

The insight into the notes to financial statements indicates that financial institutions generally disclose more extensive segment information. The statistical analysis has confirmed it. Namely, financial institutions disclose 23 pieces of quantitative segment information on average, while other entities disclose 10 pieces of quantitative information on average. The Mann-Whitney $\mathrm{U}$ test was conducted in order to examine whether the difference in the level of disclosure is statistically significant. This test is a non-parametric alternative to the independent samples t-test, which could not be implemented because the Shapiro-Wilk test showed that the distribution of the number of disclosed items did not approximate to the normal, neither for financial institutions nor for other companies ( $p<0.05$ in both cases). The Mann-Whitney U test reveals that the difference in the number of disclosed items between financial institutions $(\mathrm{Md}=$ $18 ; \mathrm{n}=14)$ and other companies $(\mathrm{Md}=6 ; \mathrm{n}=19)$ is statistically significant ( $\mathrm{U}$ $=37.5, \mathrm{z}=-3.486 ; \mathrm{p}=0.000)$. Since the indicator of the size of the effect $(\mathrm{r})$ is at the level of 0.61, it can be concluded that the nature of the entity (financial or non-financial), according to the Cohen's criteria (Pallant, 2011, p. 231), has a strong influence on the number of disclosed items.

In order to determine whether the type of entity (financial or non-financial) influences the disclosure of segment assets, liabilities, depreciation and amortization, which are important conditional (non-obligatory) items, the chisquare tests of independence were conducted. Because the observed variables have two categories, the Yates continuity corrections were made in order to compensate for the overestimated values of chi-square tests. The Cohen's 
criteria were used (Pallant, 2011, p. 222) to assess the effect size. The assumption of chi-square test with respect to the least expected cell frequency has been met in all the three cases, because the expected frequencies in all cells were not less than 5 . The mentioned tests have shown that:

- There is a small effect of entity type on disclosure of segment assets which is not statistically significant $(57.1 \%$ of financial institutions that disclose assets versus $68.4 \%$ of other entities that do so; $\chi^{2}(1, n=33)=0.09 ; \mathrm{p}=$ 0.765 ; phi $=-0.116$;

- There is a small effect of entity type on disclosure of segment liabilities which is not statistically significant $(57.1 \%$ of financial institutions that disclose liabilities versus $42.1 \%$ of other entities that do so; $\chi^{2}(1, n=33)=$ $0.252, \mathrm{p}=0.616$; $\mathrm{phi}=0.149$ ); and

- There is a medium effect of entity type on disclosure of segment depreciation and amortization, which is not statistically significant $(57.1 \%$ of financial institutions that disclose depreciation versus $21.1 \%$ of other entities that do so; $\left.\chi^{2}(1, \mathrm{~N}=33)=3.111 ; \mathrm{p}=0.078 ; \mathrm{phi}=0.371\right)$.

Based on the above, it can be concluded that disclosures of assets, liabilities, depreciation and amortization mainly do not depend on whether the entity belongs to the category of financial institutions or not.

Financial institutions and other entities are different in terms of the number of reportable segments. While financial institutions have an average of 3 reporting segments, other entities have an average of 3.84 reporting segments. As the distribution of reportable segments number, according to the ShapiroWilk test, does not approximate the normal for financial institutions $(p<0.05)$, although it approximates the normal for other companies $(\mathrm{p}>0.05)$, the precondition for implementation of the independent samples t-test is not met. The alternative Mann-Whitney $U$ test reveals that the difference between the number of segments of financial institutions $(\mathrm{Md}=3 ; \mathrm{n}=14)$ and other companies $(\mathrm{Md}=4, \mathrm{n}=19)$ is not statistically significant $(\mathrm{F}=105 ; \mathrm{z}=-1.05 ; \mathrm{p}$ $=0.294 ; \mathrm{r}=0.18$ ). Thus, the entity character (financial or non-financial) does not have a statistically significant effect on the number of reporting segments.

In order to determine whether the size of an entity affects its segmental reporting, we examined the relationship between the number of disclosed quantitative segment information pieces and the number of reportable segments, on the one hand, and the total operating revenues and total balance sheet assets, as features of an entity's size, on the other hand. For that purpose, the correlation analysis using the Pearson's coefficient (r) was conducted. With respect to the Cohen's guidelines for determining the relationship strength (Pallant, 2011, p. 137), it has been found that:

- There is no relationship between the balance sheet value of an entity's assets and the number of its reportable segments $(r=-0.037 ; p=0.837)$; 
- There is no relationship between the amount of an entity's operating revenues and the number of its reportable segments $(\mathrm{r}=0.02 ; \mathrm{p}=0.914)$;

- There is a strong and statistically significant relationship between the balance sheet value of an entity's assets and volume of quantitative segment information disclosed $(\mathrm{r}=0.517 ; \mathrm{p}=0.002)$; and

- There is no relationship between the amount of an entity's operating revenues and volume of the quantitative segment information disclosed $(\mathrm{r}=$ $0.088 ; \mathrm{p}=0.627)$.

The correlation analysis also reveals there is no relationship between the number of reportable segments and the number of the quantitative segment information disclosed $(\mathrm{r}=-0.007 ; \mathrm{p}=0.97)$.

In any case, the analysis reveals that there is a considerable diversity in external segment reporting practices of companies in the Republic of Serbia, which could be expected considering the flexibility of IFRS 8 provisions, but also that the mentioned standard is not fully respected, which is also not surprising. Namely, some previous studies conducted in other countries revealed that external segment reporting practices deviate from authoritative regulatory basis (standards). The same studies also indicated the factors influencing the willingness of companies to disclose segment information including: audit quality (in terms of auditors' attention to segment information), size, industry, financial structure, profitability and growth rate of a company, degree of ownership dispersion of a company and presence of institutional investors (Albu et al., 2013; Herrmann \& Thomas, 1996; Paul \& Largay III, 2005; Prather-Kinsey \& Meek, 2004; Prencipe, 2004).

In the available reports on audit of financial statements of the surveyed companies that disclose segment information, we do not find any notice on irregularities of this information. If we take into account the results of the research on the practices of disclosure of related parties (Jakšić, 2010), which also indicates that companies in the Republic of Serbia do not fully respect the provisions of authoritative standard (IAS 24), and the results of the research on the practices on financial reporting on property, plant and equipment, according to which some companies do not disclose measurement basis or depreciation method used (Obradović \& Karapavlović, 2014), we get the impression that preparers and auditors of financial statements in the Republic of Serbia do not devote full attention to information disclosed in the notes to financial statements.

Diversity of segment reporting practices discovered in this research and the resulting insufficient comparability of segment information of different companies indicate that the IASB should seriously consider the proposals and suggestions regarding possible improvements of IFRS 8. Namely, on the basis of survey carried out in Germany, Franzen \& Weißenberger (2015), propose to increase the volume of obligatory disclosures, and define more clearly the 
methods of segment items measurement in terms of their harmonization with the methods of measurement of corresponding items of an entity as a whole. However, the same authors rightly express skepticism as to whether and to what extent the IASB will consider amendments to IFRS 8, because this standard has been harmonized with the U.S. FASB during the process of convergence between IFRS and the U.S. GAAP. Therefore, the IASB should coordinate each possible amendment of IFRS 8 with the FASB, which, as stated above, effectively created the current IFRS 8 .

\section{Conclusion}

Segment reporting is an important instrument for supplying external stakeholders (investors and creditors, primarily) with information useful for making economic decisions. By presenting a company from a new perspective, segment information is a very useful addition to information about the financial position, performance and cash flows of the company as a whole.

The prevailing opinion in the world today is that external segment reporting should be based on segment reporting for the needs of a company's management. This approach is highly distinguished in the current international financial reporting standard which deals with this issue - IFRS 8 . Although published by the IASB, this standard is virtually created in the U.S.A. Since it is supported by the most respected setters of financial reporting standards in the world today - the IASB and the U.S. FASB - IFRS 8 can be considered a global solution. The mentioned standard is a subject of criticism, not without reason, but, in general, it can be considered as a high-quality base for external segment reporting.

The regulatory framework of external segment reporting in the Republic of Serbia currently consists of IFRS 8 . Hence, by adopting IFRS as a whole, which IFRS 8 is a part of, the authority institutions for regulating financial reporting in the Republic of Serbia have created the basis for high-quality external segment reporting. However, a quality standard, in itself, does not guarantee that the segment information disclosed by companies is really of high quality.

The research conducted in this paper reveals that segment information have a modest place in the overall information that companies in the Republic of Serbia disclose in their financial statements. A relatively small number of companies disclose segment information, while disclosed information is not always complete. Quantitative segment information is not always accompanied with appropriate qualitative information that would clarify or complete them. Incomplete compliance of the external segment reporting practices with the provisions of IFRS 8 , which has been identified in this study, suggests that preparers of financial statements, as well as auditors of these statements, should pay more attention to segment disclosures. 
At least to some extent the mentioned shortcomings are consequences of the fact that segment reporting is a relatively new area of financial reporting in the Republic of Serbia. Unlike some countries, especially the Anglo-Saxon ones, where segment reporting was developed as a response to the expressed needs for information of financial statement users, in the Republic of Serbia it has arisen as a result of adopting international standards - IFRS. In the period preceding the adoption of IFRS, this area of financial reporting had not been subject of considerable attention in the Republic of Serbia, due to underdeveloped capital market and the characteristics of the economic environment in general. It should be expected that, with the further development of capital market in the Republic of Serbia, the needs of financial statement users for detailed and high-quality segment information will increase, which will intensify pressure on preparers, auditors and regulators of financial reporting, who will have to make a greater effort in order to meet user needs.

The research in this paper has revealed that financial institutions generally disclose more extensive segment information in comparison with other companies. In addition, the relationship between the volume of information disclosed and a balance sheet value of assets of entities has also been identified, in the sense that entities with bigger balance sheet assets disclose more quantitative segment information.

\section{References}

Albrecht, W. D. \& Chipalkatti N. (1998). New Segment Reporting. The CPA Journal, 68 (5). preuzeto sa: http://www.cpajournal.com/1998/0598/Features/ F460598.htm, pristupljeno: 15 April 2015.

Albu, N., Albu, C.N. \& Mateescu, R. (2013). Analiza practicilor de raportare pe segmente - cazul societăţilor cotate la BVB. Audit Financiar, 11 (106), 32-38.

Belkaoui, A.R. (1994). International and Multinational Accounting. London: The Dryden Press.

Deppe, L. \& Omer, S.C. (2000). Disclosing Disaggregated Information. Journal of Accountancy, 190 (3), 47-54.

Đukić, T. (2002). Utvrđivanje i analiza novčanih tokova segmenata. Računovodstvo, 46 (6), 21-26.

Financial Accounting Standards Board (1997). Statement of Financial Accounting Standards No. 131: Disclosures about Segments of an Enterprise and Related Information.

Franzen, N. \& Weißenberger, B.E. (2015). The adoption of IFRS 8 - no headway made? Evidence from segment reporting practices in Germany. Journal of Applied Accounting Research, 16 (1), 88-113.

Haller, A. (2003). Segmental reporting. In: Walton, P., Haller, A. and Raffournier, B. (Eds.), International Accounting ( $\left.2^{\text {nd }} \mathrm{ed}\right)(\mathrm{pp} .444-470)$. London: Thomson.

Herrmann, D. \& Thomas, W. (1996). Segment Reporting in the European Union: Analyzing the Effects of Country, Size, Industry, and Exchange Listing. Journal of International Accounting \& Taxation, 5 (1), 1-20. 
Herrmann, D. \& Thomas, W.B. (1997). Reporting Disaggregated Information: A Critique Based on Concepts Statement No. 2. Accounting Horizons, 11 (3), 35-44.

Hoyle, J.B., Schaefer, T.F. \& Doupnik, T.S. (2004). Advanced Accounting $\left(7^{\text {th }}\right.$ ed). New York: McGraw-Hill/Irwin, International Edition.

Ijiri, Y. (1995). Segment Statements and Informativeness Measures: Managing Capital vs. Managing Resources. Accounting Horizons, 9 (3), 55-67.

International Accounting Standards Board (2005). Board Meeting: 20 January 2005, London, Project: Short-term Convergence - Segment Reporting, Information for observers.

International Accounting Standards Board (2014). International Financial Reporting Standard 8: Operating Segments, IFRS Foundation.

Jakšić, D. (2010). Regulativa i praksa obelodanjivanja povezanih strana u finansijskim izveštajima u Republici Srbiji. U: Čanak, J. (Ed.), Mogućnosti i ograničenja razvoja računovodstvene profesije u Srbiji, XLI simpozijum Računovodstvo i poslovne finansije u savremenim uslovima poslovanja (pp. 96-109). Zlatibor: Savez računovođa i revizora Srbije.

Malinić, D. (1999). Divizionalno računovodstvo: računovodstveno izveštavanje po profitnim i investicionim centrima. Beograd: Ekonomski fakultet.

Obradović, V. \& Karapavlović, N. (2014). Finansijsko izveštavanje o nekretninama, postrojenjima i opremi u Srbiji. Računovodstvo, 58 (11-12), 38-50.

Pacter, P. (1993). Reporting Disaggregated Information. Research Report, Financial Accounting Standards Board.

Pallant, J. (2011). SPSS - Priručnik za preživljavanje (prevod četvrtog izdanja). Beograd: Mikro knjiga.

Paul, J.W. \& Largay III, J.A. (2005). Does the 'management approach' contribute to segment reporting transparency? Business Horizons, 48 (4), 303-310.

Prather-Kinsey, J. \& Meek, G.K. (2004). The Effect of Revised IAS 14 on Segment Reporting by IAS Companies. European Accounting Review, 13 (2), 213-234.

Prencipe, A. (2004). Proprietary Costs and Determinants of Voluntary Segment Disclosure: Evidence from Italian Listed Companies. European Accounting Review, 13 (2), 319-340.

PricewaterhouseCoopers (2002). Europe and International Financial Reporting Standards: Your questions answered.

PricewaterhouseCoopers (2005). World Watch, No. 2.

Radebaugh, L.H. (1987). International Aspects of Segment Disclosures: A Conceptual Approach. Research Monograph No2, Department of Accounting and Finance, Glasgow Business School, University of Glasgow, Glasgow.

Radebaugh, L.H. (1997). Segmental and Foreign Operations Disclosures. In: Choi, F.D.S. (Ed.), International Accounting and Finance Handbook ( $2^{\text {nd }}$ ed) (pp. 19·1-19·29). New York: John Wiley \& Sons, Inc.

Radebaugh, L.H. \& Gray, S.J. (1997). International Accounting and Multinational Enterprises $\left(4^{\text {th }}\right.$ ed). New York: John Wiley \& Sons, Inc.

Roberts, C. (2010). Segment Reporting. In: Nobes, C. and Parker, R. (Eds.), Comparative International Accounting (11 ${ }^{\text {th }}$ ed) (pp. 454-485). Harlow: Pearson Education Limited.

Swaminathan, S. (1991). The Impact of SEC Mandated Segment Data on Price Variability and Divergence of Beliefs. The Accounting Review, 66 (1), 23-41. 
Wild, J.J. (2005). Financial Accounting: Information for Decisions $\left(3^{\text {rd }}\right.$ ed). New York: McGraw-Hill/Irwin, International Edition.

\section{EKSTERNO IZVEŠTAVANJE PO SEGMENTIMA U REPUBLICI SRBIJI}

Apstrakt: Svrha istraživanja u radu je sagledavanje regulative i praksi eksternog izveštavanja po segmentima u Republici Srbiji. Značaj istraživanja proističe iz velike potencijalne korisnosti informacija o segmentima za investitore i kreditore. Analiza regulative ukazuje na to da Republika Srbija ima kvalitetnu i međunarodno priznatu osnovu eksternog izveštavanja po segmentima - IFRS 8. Ipak, postoji prostor za unapređenje IFRS 8. Analiza praksi, sprovedena na uzorku od 500 kompanija, ukazuje na to da kompanije u Republici Srbiji, generalno, ne pridaju veliki značaj obelodanjivanju informacija o segmentima u finansijskim izveštajima. Prakse su prilično raznovrsne, što je posledica fleksibilnosti IFRS 8, ali i nepotpunog poštovanja IFRS 8. Primenom statističkih tehnika ispitano je da li su prakse eksternog izveštavanja po segmentima u vezi sa karakteristikama kompanija, u čemu se ogleda originalnost rada. Utvrđeno da finansijske institucije obelodanjuju obimnije kvantitativne informacije o segmentima u odnosu na ostale kompanije i da kompanije sa većim ukupnim sredstvima obelodanjuju obimnije informacije o segmentima. Istraživanje je ukazalo na to da postoji značajan prostor za unapređenje praksi eksternog izveštavanja po segmentima u Republici Srbiji. Rezultati istraživanja mogu biti od koristi za regulatore finansijskog izveštavanja i sastavljače i revizore finansijskih izveštaja.

Ključne reči: finansijsko izveštavanje, izveštavanje po segmentima, obelodanjivanje, IFRS 8, operativni segmenti

\section{Authors' biographies}

Vladimir Obradović was born in 1978 in Užice. Primary and secondary school finished in Kosjerić. Basic academic studies at the Faculty of Economics in Kragujevac in 2002. Master's degree from the Faculty of Economics in Belgrade in 2007. Thesis was defended in February 2012 at the Faculty of Economics, University of Kragujevac. He works at the Faculty of Economics, University of Kragujevac as a Assistant Professor. He teaches subjects Financial Reporting (undergraduate studies), the Special Balances (master academic studies) and the International Financial Reporting (doctoral studies), closely related to accounting, auditing and business finance. His scientific interests are related to the field of financial reporting, specifically for the international aspects of financial reporting and financial reporting standards.

Nemanja Karapavlović was born in 1987 in Čačak. Elementary and secondary school finished in Čacak. Basic academic studies at the Faculty of Economics in Kragujevac in 2010. There he completed a Master's degree studies in 2012. Currently a student of third year of doctoral studies at the Faculty of Economics, University of Kragujevac (Module: Accounting and Business Finance), where he works as an Teaching Assistant at the Financial Reporting (undergraduate studies) and special balances (master academic studies). Spheres of his scientific interests are external financial accounting and reporting, general purpose and financial reporting on special occasions. 